\title{
Heritage Protection in Pécs/Sopianae
}

\author{
Tamás Molnár \\ University of Pécs, Pollack Mihály Faculty of Engineering and Information Technology \\ Hungary
}

\section{Introduction}

Pécs is a historic city. A unique symbiosis of four important historical ages, namely the Roman Age, the Middle Ages, Turkish times and the late Baroque Age is present in the city. The topography of Pécs, together with the large green areas in the downtown, forms a special architectural neighbourhood.

The Late Roman, Early Christian cemetery of Pécs had already been discovered by 1780 . Since then, preservation and exhibition of the cemetery has been of continuous importance for everybody. As a reflection of several hundred years work on the Early Christian cemetery of Sopianae (Roman name of Pécs), the site was awarded World Heritage status in 2000.

Over the last 40 years, research and planning works of the burial site has been carried out by Prof. Dr. Zoltán Bachman and his colleagues from the University of Pécs, Pollack Mihály Faculty of Engineering and Information Technology. Over this time a university course was established in the field of architecture, and later the Marcel Breuer Doctoral School was founded, where the main research field is heritage protection. With the foundation of the doctoral school, an important research base of heritage protection was established.

Several important projects were carried out over the last few years. The Cathedral Museum was built to provide a place to house the original stonework of the Cathedral, originating from the 12-13 th century. The northern and the western walkways along the town walls were constructed as important green areas of the downtown. Preservation of the Early Christian Mausoleum and of the burial sites in Apáca Street, together with the construction of the Cella Septichora Visitors' Centre, represented a great challenge for the architects and engineers. During the archaeological works of the Cella Septichora, the seven burial chambers located around it were also preserved. Nowadays all of these chambers and burial objects can be visited from the visitors' centre.

The City of Pécs has two main squares. The religious main square, in front of the cathedral is connected to the civil main square by a promenade that was reconstructed during the works of the Cella Septichora Visitors' Centre. The moving bell-tower of St. Bartholomew and the building of the Archaeology Museum mark the beginning of the promenade.

\section{Methodology}

The question was the same at every archaeological site: how to start the works. Foreign projects were studied but did not provide much insight because in Italy the conditions were 
so favourable that they only had to ask for an admission fee at similar archaeological findings. The Bulgarians replicated the artefacts for the public and the Romanians simply blocked access of the archaeological sites. However, it was a Bulgarian building engineer who helped the team of Prof. Bachman. This expert achieved great results in the field of treating the air. His expertise opened new paths in the approach of the planners.

\subsection{Basic questions}

Three basic questions needed to be solved to save the archaeological sites in Pécs:

Firstly the painted burial chambers had to be isolated from the earth surrounding them, so they could no longer get contaminated by micro organisms breeding in the moisture which destroy the frescos. The solution was the establishment of a buffer zone, that is, a system of corridors surrounding the archaeological artefacts, the burial chambers. Secondly, constant air quality had to be secured as this is optimal for the frescos. In the special climate the temperature should be $13^{\circ} \mathrm{C}$ and relative humidity should be $55 \%$. Special glass structures had to be designed to protect the frescos. Thirdly, the question was how to work securely but efficiently underground. The answer was given by miners, by Swabian excavation crews from the Mining Company in Dunaszekcső. They were brave and comfortable in at least four different trades, most of them were real artists of manual labour. They had intelligent hands (Bachman, 1989).

\subsection{Problem of understandable presentation}

Maybe the hardest question for each project was how to present the protected archaeological site to the visitors in a way that they can also understand what they are seeing. The solutions came through special views, natural light, transparency or clear visibility from different angles for the architects. The most important point at the world heritage site of Pécs was to make it clear for visitors that this cemetery was above the ground in the $4^{\text {th }}$ century AD and this is what differentiates it from any other Early Christian archaeological site of the world.

\section{The Cathedral Museum}

The Cathedral Museum can be found in front of the vaulted passageway leading towards Pécs' Cathedral. It was sunk into the area of a former moat, between the walls of the bishop's castle and the contrascarpa, which was then filled up, in the Baroque Age. This considerable building was turned into an almost hidden, subterranean anti-building, providing a spacious interior to house the collection of the Cathedral (Bachmann, 2010).

\subsection{Stone findings of the cathedral}

The Cathedral of Pécs, founded in 1009, preserved outstanding architectural and sculptural elements from the $12^{\text {th }}$ and $13^{\text {th }}$ centuries even on a European scale. In the $19^{\text {th }}$ century it was reconstructed following Purist principles according to the plans of Frigyes Schmidt, a German architect. The original stone sculptures were replaced by new, reconstructed elements (see Fig. 1).

Because of the reinterpretation, frequent reconstruction and completion of the Romanesque and Gothic architectural elements, the original stones were forced to wander for decades, 


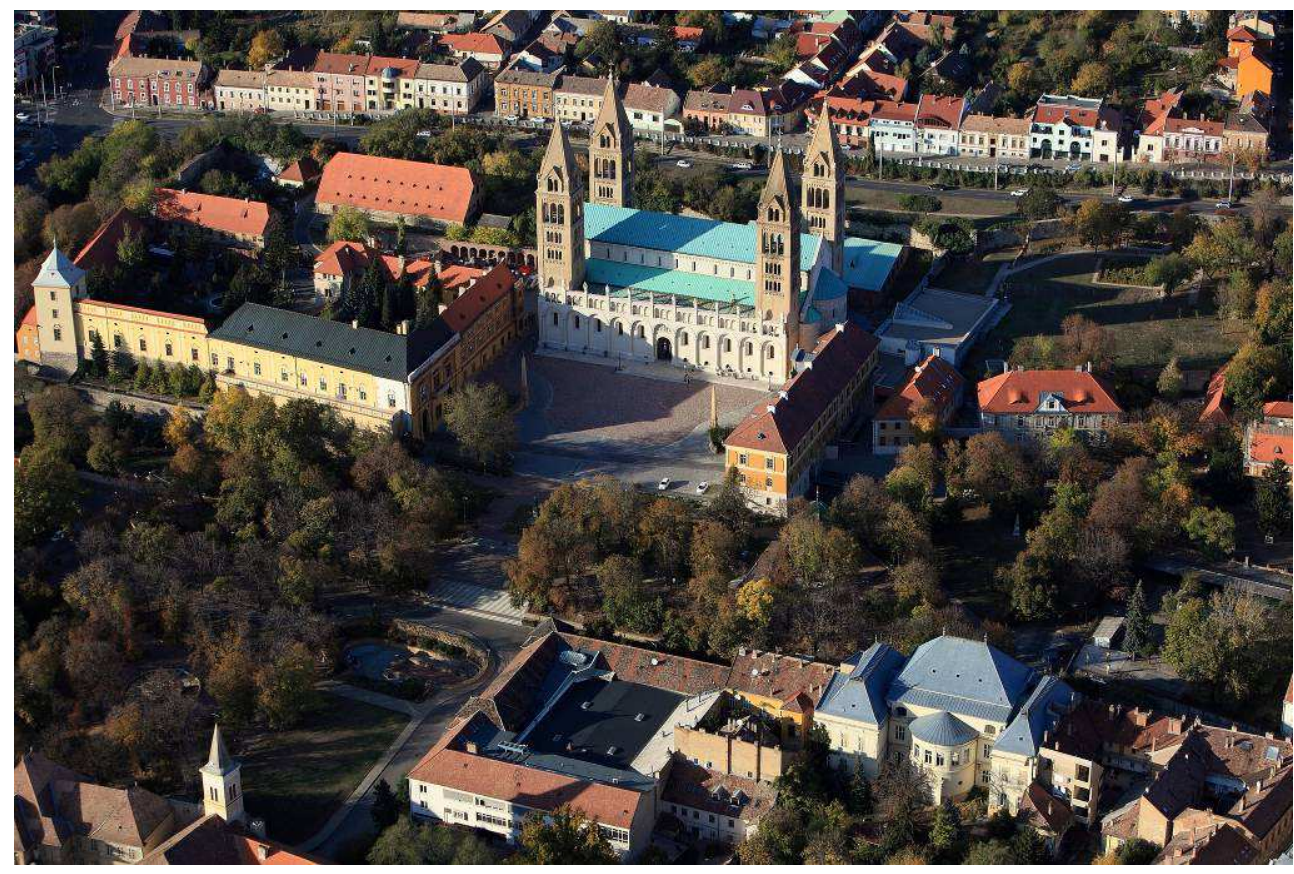

Fig. 1. The Cathedral and next to it the Cathedral Museum

being taken to various locations several times. A Cathedral Museum was really needed to establish a suitable place to display the original stone sculptures.

In the 1880s a find of stone-sculptures and architectural carvings was made in Pécs, the largest one that had ever come to light in Central Europe. In the course of the reconstruction of the Cathedral more than a thousand stone carvings were uncovered, providing evidence of a stunningly rich church decoration; it was unique in Romanesque Hungary and was rarely matched in the neighbouring countries. The exceptional discovery created a nation-wide sensation at the time and generated an international interest in scholarly circles. These decorations were made in the second half of the $12^{\text {th }}$ century, an exceptionally prolific period of Romanesque sculpture. They embellished the church interior, primarily the central area between sanctuary and nave. It was precisely in this zone that the most outstanding sculptural ensembles were uncovered in the late $19^{\text {th }}$ century. The ruins found at the centre proved to be the remains of a lavishly adorned small edifice, while the stairs descending from the nave to the crypt were framed by unusually high walls with relief decorations.

The Altar of the Holy Cross (see Fig. 2) stood on a separate platform in the very centre of the Romanesque church, a place determined by its liturgical significance. The altar was enclosed in a vaulted structure gorgeously decorated both inside and outside with carved ornamental reliefs, gilding and polychromy; placed in the church's interior, this small building must have looked like a large jewellery box. The masters who accomplished them imported the 


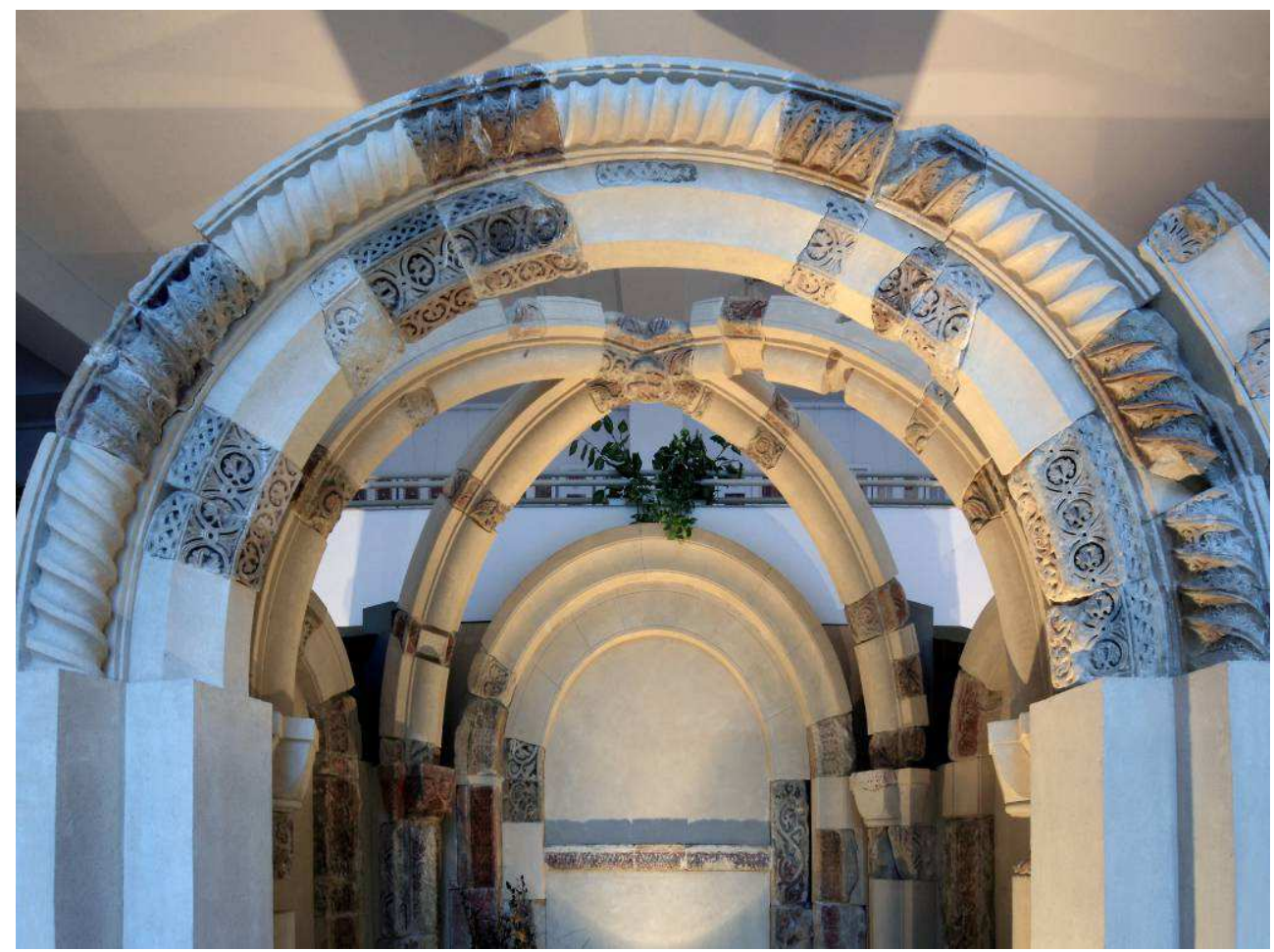

Fig. 2. The Altar of the Holy Cross

traditions of Northern Italian ornamental stone carving to Pécs. In the process they created a unique work of art: such a lavishly decorated altar baldachin in the shape of a building is unparalleled in the whole of Europe. As indicated by a further series of carvings, decoration of this kind was not absent in the area around the altar either.

The abundance of ornaments and colours were integrated within the narrative framework of large-scale relief cycles, which covered the walls of the entrances to the crypt. Their images spanned all that medieval man considered to be his past and future: the history of Salvation, from Genesis to the Last Judgement. It was an immense and ambitious programme, paralleled by only a few similar works in contemporary Europe. To carry out the plan, a number of outstanding masters were invited from abroad, which mediated recent trends in sculpture from France and Northern Italy. The walls of the southern entrance to the crypt were decorated with parallel cycles of the life of Christ and that of Samson, a hero in the Old Testament. They rank among the greatest achievements of medieval art in Hungary, while some of their scenes, for example, the Three Magi and the Passion of Jesus or the story of Samson are also regarded as remarkable works of universal Romanesque sculpture. In the presentation of the Creation and Adam and Eve in the northern entrance to the crypt, local craftsmen were also engaged. They were equally responsible for the sculptures of the elders of the Apocalypse and the angels. One of these figures, an exceptionally well preserved and 
beautiful angel (see Fig. 3), escaped the usual fate that befell most of the stone carvings in Pécs during the Ottoman occupation, since it had been incorporated into the Gothic triumphal arch of the sanctuary.

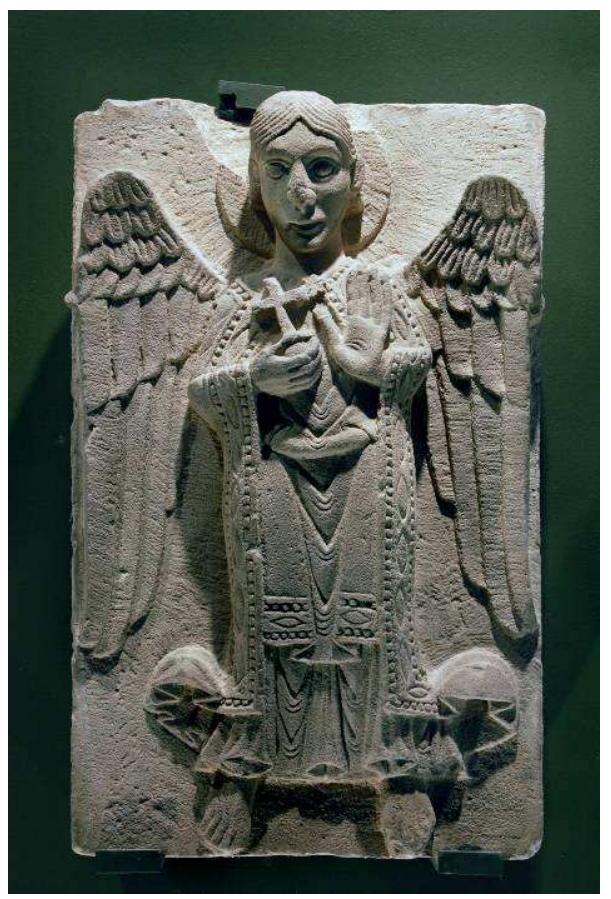

Fig. 3. The figure of the angel

In the opinion of the $19^{\text {th }}$ century restorers of the Cathedral, the uncovered remains of the once so splendid Romanesque decoration were too fragmented to be incorporated into the new church. The only acceptable solution seemed to be replacing them with copies reflecting the tastes of the time; the entrance to the crypt is now decorated with such copies. Detached from their original contexts, the carvings became pieces in a sculpture collection. During the one hundred-year history of the collection, periods of exhibitions alternated with spells of confinement in storerooms. Owing to the dampness of its walls, the last venue of the stone carvings, the Romanesque Lapidary Museum closed its doors more than twenty years ago. That was the time when the collection's confinement to storerooms began eventually ending up in a cinema in a village near Pécs, the eighth station in the calvary of the stone carvings. In the meantime a generation grew up for whom these splendid relics of medieval Hungarian art and European culture simply do not exist.

Having been made homeless, the stones of Pécs' cathedral were almost added to the long list of Hungarian cultural losses. The decisive turn in their fate came as a result of the concerted efforts and financial support of central and local authorities - the Ministry of Culture and Education, the Hungarian Bureau for the Protection of Historical Monuments, the City 
Council of Pécs, the County Council of Baranya, and the Janus Pannonius Museum of Pécs as well as of the Bishopric of Pécs. On their initiative, the Pécs Cathedral Museum Foundation was created in 1990. Its trustees launched a dynamic action for the physical presentation and cultural survival of the collection with two objectives: the conservation of the stone carvings and the construction of a new Cathedral Museum. The conservation was the first comprehensive effort of this kind in the history of the collection. The carvings were cleaned, the condition of the stones was stabilised, and a good part of the strongly faded polychromy, along with important portions of gilding, was successfully recovered. The substantial financial support of two prestigious foundations from the United States (the Grant Program of the J. Paul Getty Trust, Los Angeles, and the World Monuments Fund, New York, administrator of the Samuel H. Kress Foundation's European Preservation Program) played a major role in the conservation, and so did the generous donations by a group of Hungarian-born American citizens.

\subsection{Concept and structure of the museum}

The two castle walls provided the western and the eastern walls of the museum. The building had to be confined with the help of a buttress from the north, while from the south a glass screen entrance was constructed. Simultaneously, visitors were given the opportunity to walk up on top of the Cathedral Museum to the exhibition, providing a modern, wonderful spectacle of the sanctuary of the Cathedral from an angle never seen before. The architectural heritage of the Middle Ages, the church architecture in this case

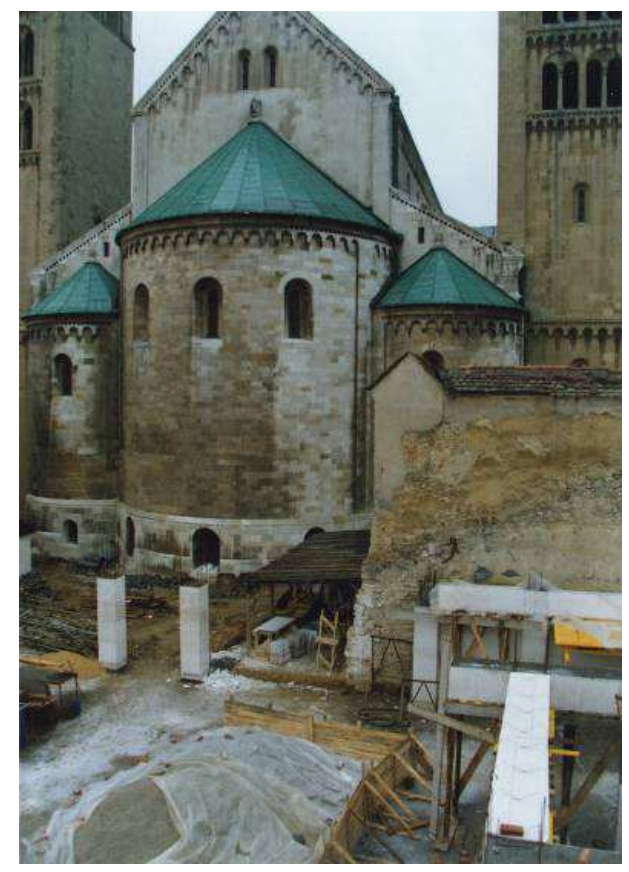

Fig. 4. Construction site of the Cathedral Museum in the former moat 
remained quite fragmented because of the storms of history and the reconstructions of different ages. Because of this, the cathedral's collection of stone findings is represented in a way that these priceless treasures can be seen in almost their original setting. (see Fig. 4)

The basis of the architectural concept was to place the western gate, the Altar and the two access ways in the same way as they could be found in the Cathedral. Owing to the incomprehensible and inexplicable resistance of art historians, the architects have not managed to achieve this. It was also an important architectural consideration that regarding its view, the large subterranean museum should somehow be connected to the Cathedral. It has been achieved with the help of a glass wall that was cut into the western wall of the Bishop's Castle. The glass wall continues in the form of a wedge shaped glass ceiling. Thus the view of the Cathedral meets the eyes of the visitors in the museum, helping them to identify the former location of the stone findings; where the gate, the Altar and the entrance to the crypts were located in the original Cathedral. In addition to the regular planning work the architects had to struggle with two other things: to find funding for building the museum ; and as the construction of the museum was extremely slow, the concept had to be created according to the most modern principles.

The concept of the museum building follows the idea of the 'house in the house' composition. Damp-proof insulation of the building guaranteed protection from the moisture of the soil. In the construction at the museum, gypsum-concrete was applied, also known as frosted concrete, the patent of Béla Sámsondi Kis. At that time, the person responsible for the patent, István Szövényi, used to work for the Hungarian Bureau for the Protection of Historical Monuments, therefore the Bureau could also provide financial support to develop a new building under the pretext of technical improvement. The neutral appearance of the structure is perfect for establishing a museum. The structure achieved unparalleled solidity. Three centimetres of special consistency concrete is sandwiched between two $1 \mathrm{~cm}$ thick $60 \times 60 \mathrm{~cm}$ gypsum panels with steel reinforcing. As the gypsum solidifies it absorbs water from the concrete creating the so-called 'frosted concrete' whose strength is outstanding. The longest span is 12 meters which is loaded in the middle. The presence of gypsum regulates the humidity in a natural way. Hans Hollein had already applied this material in a museum in Mönchengaldbach. The structure had another great advantage: the site was so narrow that it was impossible to use cranes to build the structure. When constructing the building, migrant workers from Romania worked on the project under the leadership of a project supervisor. The potential provided by these traditional tradesmen could be utilized, who even made the tools for the technology themselves. The facades provided great opportunities. The subterranean building emerges with two facades: the western façade whose main constituting element is the wall of the Bishop's Castle. The large glass wall was concealed here, interrupting the castle wall for didactic purposes and also continuing it as this joins the 'new castle wall' that follows the path of the former wall. This new wall is made of sandstone similar to the stone of the Cathedral. An emergency exit, a castle gate has also been built into the wall. The southern façade stimulates viewers with its strong colours. This was a conscious decision, as strong and vivid colours were popular in the Middle Ages. The dead and tired colours of its surrounding allow, what is more, demand the appearance of a bright red facade. (Bachman \& Bachmann, 2010)

The interior of the museum has a simple double-deck arrangement. The way the gate, the altar and the passageways leading to the crypt dominated by stonework are displayed, 
compiled and made understandable, together with the technical details, are absolutely outstanding. Integrating this fragmentary collection of stonework findings has always been a problem. The stone restorer, Vilmos Osgyáni came up with an original idea. He created a steel structure similar to the shelves we can find in the pantry of our grandmother. Stainless steel "shelves" connect the superstructure and the jointing of the stones. Using this solution the stones are stabilized by their own weight. The stones were built together clearly without being damaged in any way. It is perfectly visible that the medieval gate was made of Roman tombstones (Romváry \& Szilágyi, 2005).

The collection of the Cathedral Museum, which is an outstanding example of European culture, is now in a safe place. The museum (see Fig. 5) should remain a neutral architectural framework fitting in its environment, and should also be attractive. It should provide, as far as possible, an interactive museum presentation. The main block of the museum was built into the former moat, so it fits into its surroundings, the Cathedral, as a quasi anti-building: in which the brilliant stone sculptures of the medieval Cathedral play the most important role.

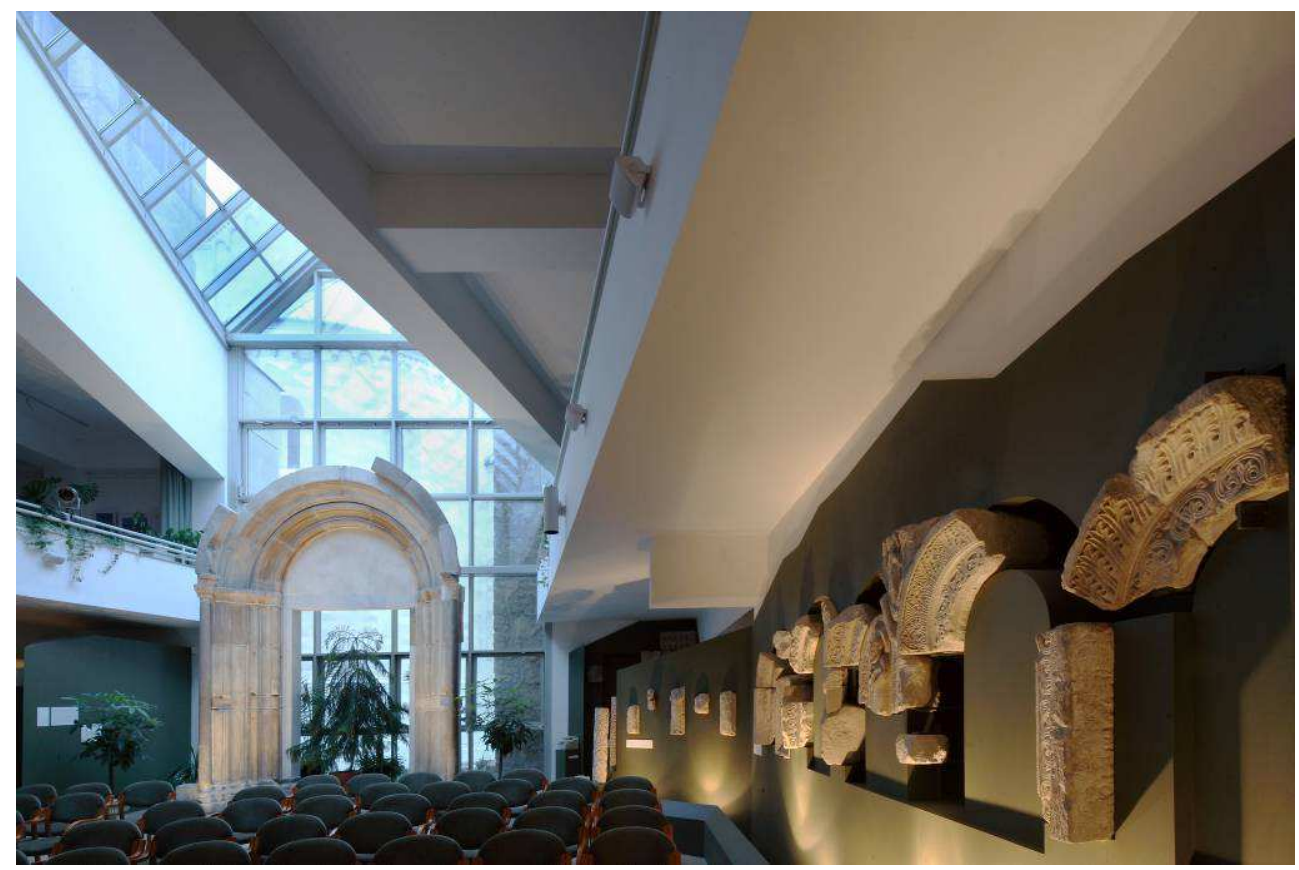

Fig. 5. Inside the Cathedral Museum

\section{The Early Christian Cemetery}

The Early Christian Cemetery Complex of Sopianae was established in the 4th century A.D. The cemetery ruins, which were initially at ground level in the Late Roman Era, now lie underground in the historical city centre, near the Cathedral. Below the surface were several 
hundred tombs. Of these, a seven-celled tomb (Cella Septichora), and a three-celled pentagon shaped tomb (Cella Trichora) were excavated on two levels. The challenges of preservation were solved by isolating the tomb from the surrounding soil and creating an environment with a constant air condition. When displaying the cemetery the architects tried to retain the experience that would have greeted those first archaeologists who excavated the 1600 year old Christian cemetery.

\subsection{Early Christian Mausoleum}

The Early Christian Mausoleum was discovered during the reconstruction works of the cascade in front of the Cathedral in Pécs and was opened to the public in 1986. The Early Christian building was reconstructed in 2007 (see Fig. 6).

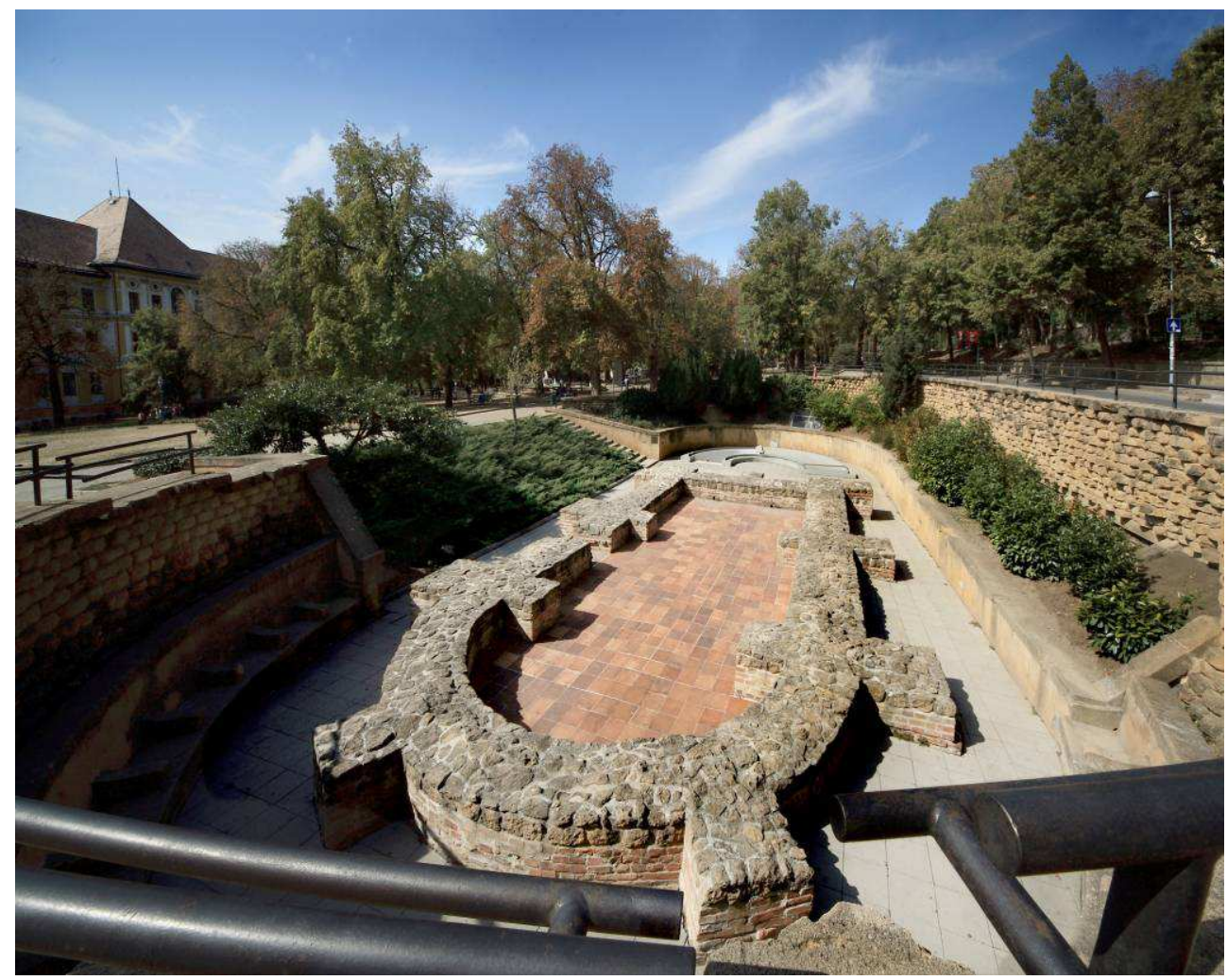

Fig. 6. The ground walls of the Early Christian Mausoleum

Three people positively influenced the planning process of the mausoleum. The first was Ferenc Mendele, who asked Dr. Zoltán Bachman to introduce the Early Christian Mausoleum, discovered when reconstructing the cascade in front of the cathedral (Bachman \& Bachmann, 2001). The archaeologist at that time was Ferenc Fülep, who was also the director-general of the National Museum in Budapest at that time. He believed in the concept of the architect. Finally the project was further reinforced by the trust and love of 
Archbishop József Cserháti. Unfortunately over the following years, the three who played such an important role at the beginning, passed away. That was the time when a group of students joined Prof. Bachman as creative partners.

The plans were conceived under favourable circumstances: the project won a silver medal at the Architecture Biennale in Sofia, internationally confirming that the concept was right. To make the site readily comprehensible for the general public, the mausoleum, which had been below street level for centuries, had to presented in the following way: the part of the building that was originally under the ground in Roman times should remain under the surface while the part that was above the surface should recall the sunny world of the Mediterranean. Therefore the architects decided to present the remaining meter-high ground walls of the huge, one-nave building of the mausoleum in an amphitheatre-like opening so the visitors could view the site from the present surface.

The underground world of the burial site has been separated from the surrounding soil with a corridor built around the burial chamber, which makes it possible to walk around the chamber and also protects the back wall against the potential danger caused by water entering the site. (see Fig. 7.) The Early Christian Mausoleum was opened to the public in 1986. Since then the condition of the building has decayed. In 2007 the Early Christian Mausoleum was reconstructed with the help of EU funds. (Bachman et al., 1988)



Fig. 7. Frescos and a carved sarcophagus inside the mausoleum

\subsection{Wine pitcher burial chamber}

The wine pitcher burial chamber received its name from the wine pitcher that was painted on the wall of the chamber. It is also unique that the building can be accessed through the 
wine cellar of the Baroque parsonage, giving visitors the chance for architectural time travel, experiencing the beautiful Baroque vaulting techniques.

The way the architects presented the Wine Pitcher burial chamber was relatively well paved. The principles of protection were similar to those of the Early Christian Mausoleum. The only difference lay in how the visitors could see the site. While in the case of the Mausoleum the visitors enter a glass box separating them from the regulated air-conditioned space where the frescos were, here, owing to the small size of the chamber it was impossible to achieve this. The frescos of the chamber were saved by the restorer Attila Pintér. The chamber was isolated with the surrounding corridor, which provides a space that levels off the greater air pressure inside the burial chamber and also protects it. However, the visitors, who could only look through a small door, and could not see the frescos. The vaulting of the chamber had collapsed. The architects used this opportunity to put glass vaulting over the chamber (Bachman, 1990). Through the glass structure visitors can see the mystical space of the chamber. To add the experience that the whole building was under the ground a winding staircase was needed leading the visitors from the area in front of the chamber up to the upper level, the reconstructed Roman ground level, where the ruins of the walls of the chamber are preserved in situ (see Fig. 8). Today the chamber is connected to the Cella Septichora Visitors' Centre.



Fig. 8. Wine Pitcher burial chamber under the glass vault

\subsection{Peter and Paul burial chamber}

The Peter and Paul burial chamber received its name from the portraits of the two apostles that are painted on the vault of the burial chamber. The location is really unique as the 
burial building can be found immediately in front of the south-eastern tower of the cathedral, nowadays 8-10 meters below the ground. It was discovered in 1780 so it has suffered several intrusions (Bachmann, 2002).

Despite the experience and knowledge gained in the case of the protective buildings of the Early Christian Mausoleum and that of the Wine Pitcher burial chamber, the Peter and Paul chamber posed the most difficult challenge. Its location was already a matter of concern.

The most important exploration from earlier times took place in 1913 using the plans of István Möller (see Fig. 9). He found a brilliant concept that was similar to the idea of Frigyes Schulek who designed a protective chapel resembling the Fishermen's Bastion in Budapest (see Fig. 10). According to the concept the chamber was separated from its immediate environment, was surrounded with a protective building and the air was ventilated between them using pressure differences.



Fig. 9. The plan for the protective building of the burial chamber by Mr. Möller

Unfortunately the dampness of the air created an ideal environment for the growth of microorganisms. A further danger appeared in the form of the visitors who further 


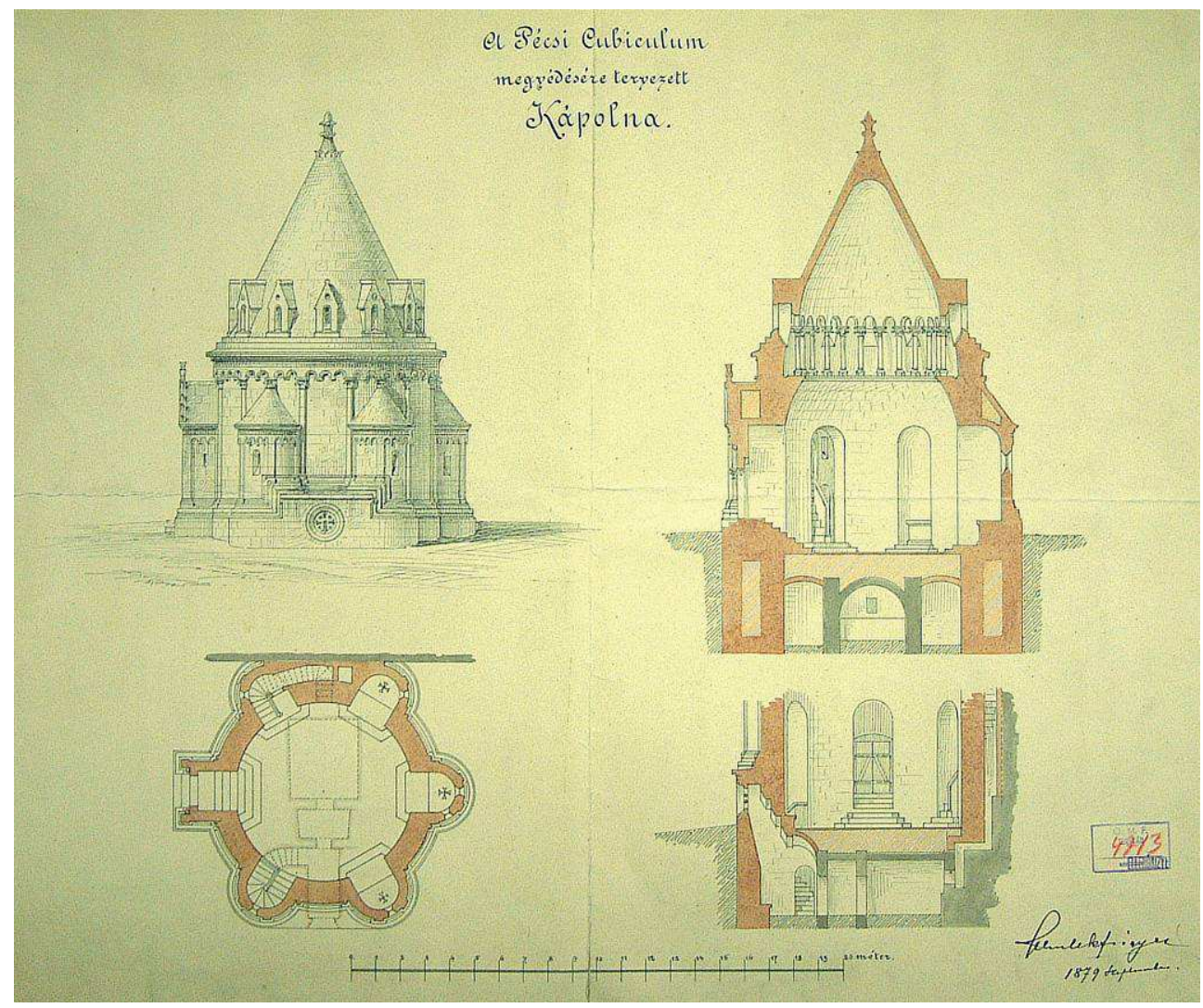

Fig. 10. The protective chapel of Frigyes Schulek

introduced pathogens on their body and breath. Möller's design included a masonry structure for the protective building. In reality however, being an excellent engineer, who was well acquainted with reinforced concrete, he decided to try this method and left the wooden formwork there, which presented another medium for microorganisms. In the end, the protective building of Möller had to be destroyed. It was a superhuman task to demolish the protective building. The more than hundred year-old concrete structures had to be demolished. It was the miners who again rose to the challenge. Using special diamond drills they drilled several holes into the reinforced concrete structure, placed steel cylinders, cut in half into them, and then put the jackhammer into these to destroy the concrete without creating any vibration. The work took half a year. As the chamber lay at the foot of the south-eastern tower of the cathedral, the architects had to unearth the foundations of the tower, too. This was only possible if the workers excavated a horizontal shaft into the unbroken soil below the level of the burial chamber. The big surprise was that the tower had no foundations. Finally soil beneath the tower was reinforced with a jet-grouting method that solved the stabilization of the tower. (Bachman, 2009a). 
The concept of protection was the same as in the case of the previous burial chambers: the painted chamber had to be isolated first, then ideal air conditions had to be established, a slight pressure had to be created inside the burial chamber to make the humidity move outwards and not condense on the surface of the frescos and because of the greater pressure a buffer zone had to be built, that is a system of corridors surrounding the chamber. The chamber had been protected this way, but unfortunately the visitors were unable to see the frescos. The architects had to do something for the chamber with the most beautiful frescos. Finally they decided to build another ground floor underneath the floor of the chamber. This was the level the workers had already traversed when the research tunnels were drilled to reveal the foundations of the tower. Walking down a winding staircase and through a corridor, visitors find themselves underneath the floor of the burial chamber that has been replaced with glass (see Fig. 11). Visitors enjoy a wonderful view as a biblical world unfolds in front of their eyes: the allure of Paradise welcomes the visitors on the frescos as the late inhabitants of the burial chamber won the grace to be in Paradise because they suffered martyrdom for their faith. People entering the Peter and Paul burial chamber become silent. Something touches the visitors' heart.

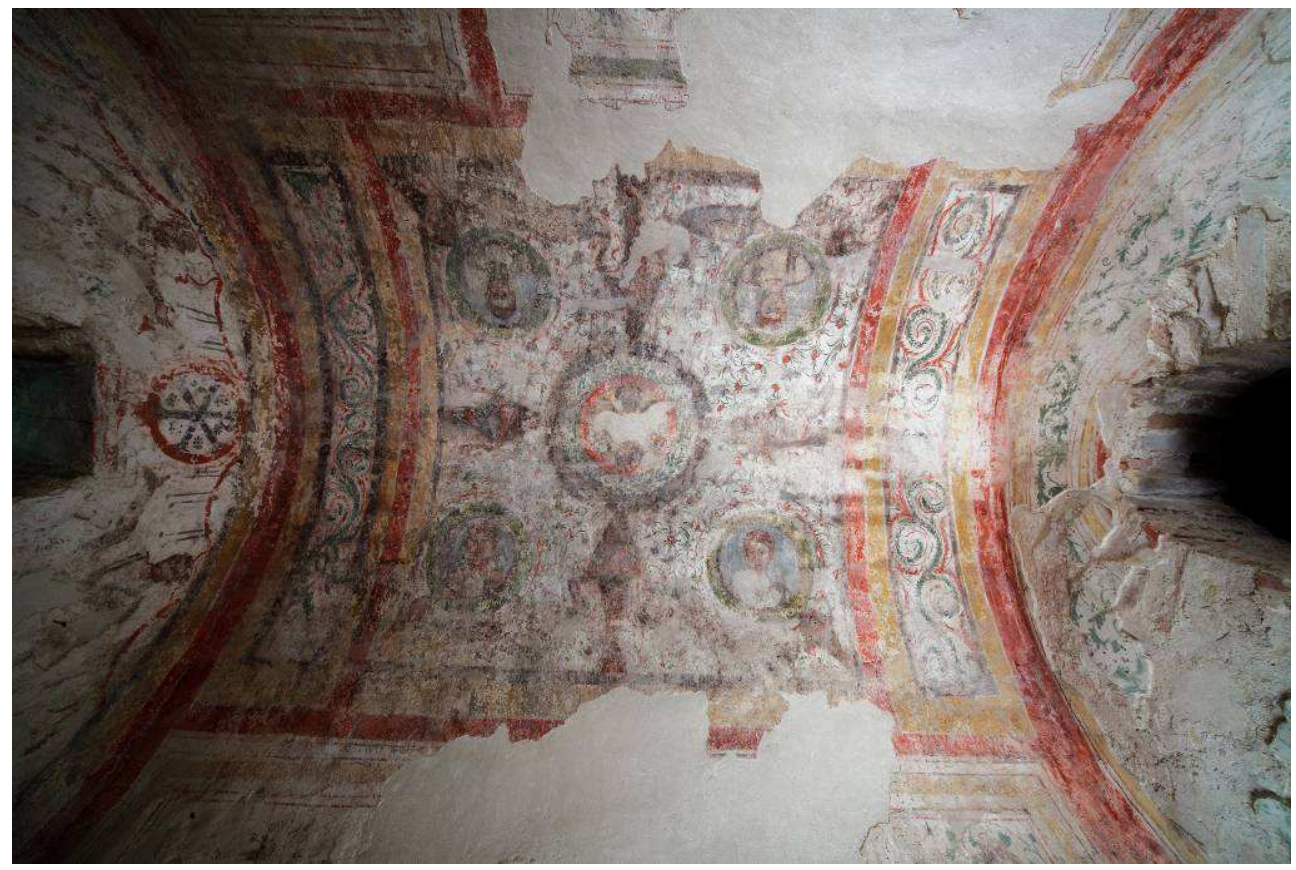

Fig. 11. View of the painted vault in the Peter and Paul burial chamber

The edifice to the east that the architects believed to also be a burial chamber was also enticing, therefore the planners built the eastern wall of the protective building in a way that could be easily demolished and would not prevent future exploration. In connection with the Peter and Paul burial chamber, also burial chamber No. III was placed under protection. This chamber is closely attached to the Peter and Paul burial chamber from the west. A part 
of the reinforced concrete protective structure of Möller was left here as a memento. The architects did not risk demolishing it because of the danger of damaging burial chamber No. III.

\subsection{Baptistery}

The early Christian building of the baptistery is also known as Burial Chamber No. V. This building has a single floor, an octagonal shape and an antechamber. The baptistery has the tallest Roman walls that exist in Hungary, further enhancing the importance of the Early Christian burial ground. During the excavation works a stone window was also discovered.

The baptistery is another major burial chamber that is located east of the Peter and Paul chamber. Owing to its location at the bottom of the tower, Möller demolished the northwestern part of the octagonal walls so he could underpin the south-eastern tower of the Cathedral with reinforced concrete. Beautiful and mysterious architectural details were revealed that will require the explanation of archaeologists in the future.

Since the edifice is in the immediate vicinity of the Cathedral, it seemed useful to build in a skylight, so a $3 \mathrm{~m} \times 3 \mathrm{~m}$ glass slab was built into the surface of the Cathedral Square making it possible to see the tower. This idea also adds to the historical continuity of the site.

Burial chamber No. V. lies completely under the surface of Cathedral Square so the incoming light makes people feel as if they are walking on the ground level of Roman times. The steel grid pavement is an important element because, on the one hand, hanging from the ceiling of the protective building above the floor of the edifice it seems to be floating in the air providing an ideal view for the visitors. In addition, it isolates the people from the ruins and finally, it illustrates the ground level of the former cemetery. In fact, it is the Cella Septichora Visitors' Centre that makes the pavement attached to the slab important as it leads the visitors through the site (see Fig. 12).



Fig. 12. Visitors on the steel grid structure looking up to the tower of the cathedral 


\subsection{Cella Septichora Visitors' Centre}

Cella Septichora is the name of the Early Christian building which has a special elliptic form with seven apses around it (see Fig. 13). The centre provides a single framework for all other Roman and Early Christian wonders. The architects aimed to make the underground cemetery visible in a way that the visitor could get an impression of the cemetery when it was in the sunshine. This task was solved by building a $300 \mathrm{~m}^{2}$ walkable glass-cover over the burial chambers, which also allows Cella Septichora to be viewed from street level (Bachman, 2009b).

Great poets usually had two topics to write about: death and women. The Early Christian Cemetery - a poem of Győző Csorba, the Kossuth Award-winning poet, led Prof. Bachman to visualize the concept. The poet, who, as a librarian, used to work next to the archaeological sites, watched the excavation works of the Early Christian cemetery from the windows of the library and witnessed archaeologists digging out the skeleton of a woman.

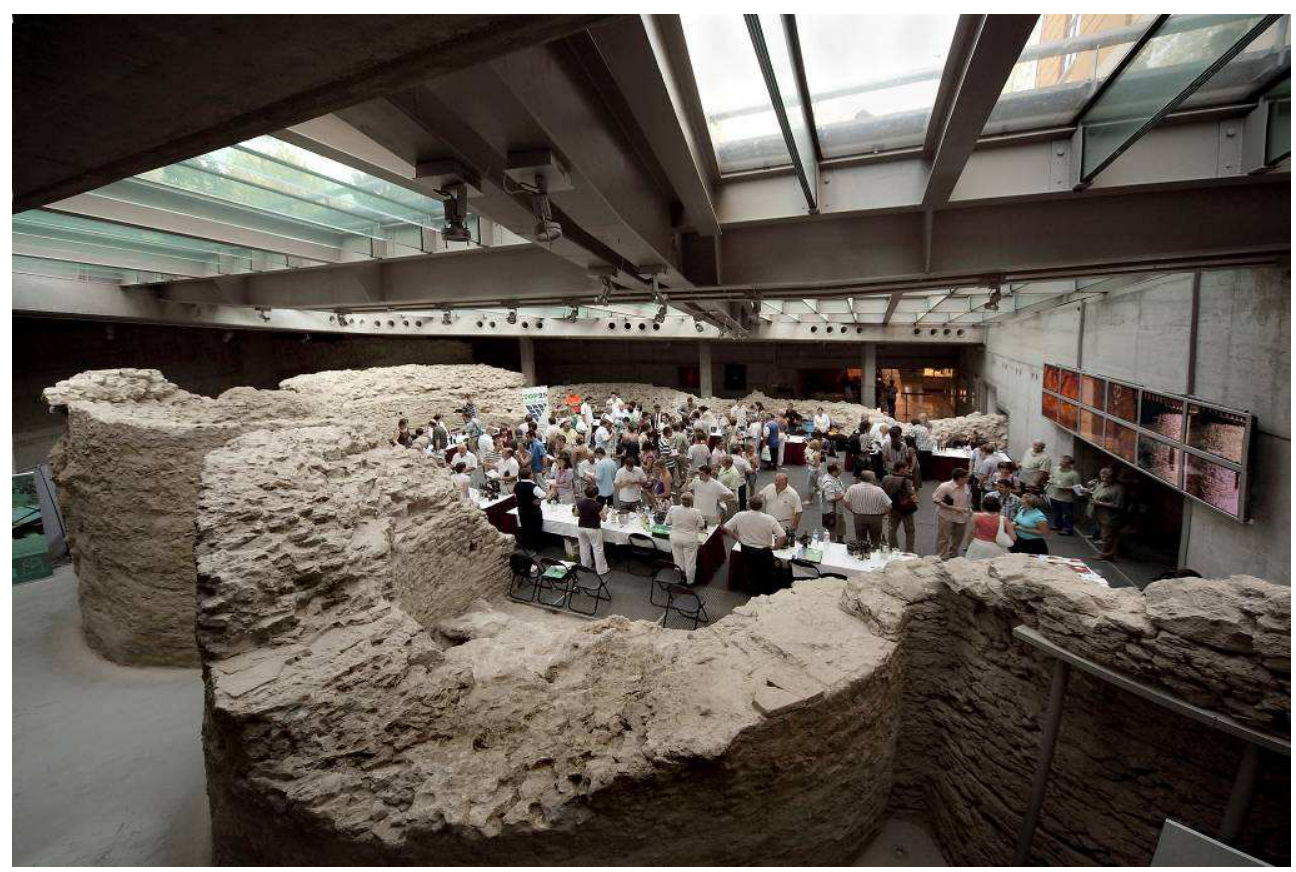

Fig. 13. Inside the Cella Septichora Visitors' Centre

Mr. Csorba described how she was lying there and imagined her coming alive. The poet 'clad' the woman with flesh and blood and muscles and the woman stirred and got up. According to the architectural concept, the world of graves is covered with a glass ceiling where Heaven may be contemplated from underneath: looking from the graves in the hope of resurrection. However, looking down, visitors can see the dark field of graves and between them the frescos of the fall and resurrection explaining the abstract state of the other world. 
Funding from the European Union that the architects could apply for in relation to the 'Cella Septichora' provided the financial backing to establish the architecture required by the vision. Because of the funding process, the architects had to produce an authorization plan before the archaeological excavation. This created a bizarre situation where the construction of the protective building took place at the same time as the excavation creating a lot of tension between the archaeologists and the architects.

During the excavation works south of burial chamber No. V, incredible new findings were discovered. Thanks to the excavations of the archaeologists, the planners managed to locate the entrances of the new chambers and clarify the way the corpses had been taken into them. It was absolutely necessary to present the new findings, as it became an indispensable connecting area in the topography of the cemetery. A completely new type of burial building was discovered, which confirmed the reason why the area should become part of a world heritage site. The ground plans of the newly discovered chapels, that are named chapels No. XIX and XX, are semi-circular. These types of chapel had never been previously found. Here in the case of Pécs, this is the only Early Christian cemetery in Europe and possibly in the world, which is above ground. If Prof. Bachman wished to express high thoughts he could say that the Early Christian architecture itself was born here as a result of the Early Christian cemetery, because before that time, when this new faith was still illegal, its believers could only bury their dead in secret and under the ground, for example in the catacombs of Rome, while in Sopianae, believers could build small chapels over the burial chambers.

It was not only the Romans who valued the area of the cemetery, the people living here in the Middle Ages also made it the centre of their bishopric. It was a great responsibility and possibly forbidden to intrude into this fantastic symbiosis of historic monuments. Therefore the architects connected the various sites under the ground with the help of steel gridstructured bridges suspended from the concrete ceiling that is meant to symbolize the original surface level of the Roman cemetery. According to the architectural concept, light is allowed to enter the underground burial sites through a glass slab that is at today's street level to make people understand that they are not walking in catacombs but among chapels that once existed above the ground. This is how the Cella Septichora Visitor Centre was born, whose entrance opens from the promenade in front of the cathedral (Baliga, 2007). The entrance has a symbolic meaning as made from a massive transparent concrete gate with a small stream flowing next to it, which refers to this Early Christian symbol, water. The transparent concrete called LiTraCon is the invention of Áron Losonczy, a Hungarian architect (see Fig. 18). The stream flows over part of the glass slab, giving light to the corridor that leads visitors to the huge hall of the Cella Septichora, the seven-apse burial chapel, which is covered by a $300 \mathrm{~m}^{2}$ glass ceiling. This is supported by a cross-shaped bridge serving as a representative pavement for the bishop. At night, when it is illuminated, the cross lying on the glass surface further reinforces the Early Christian symbols.

From the entrance hall of the Cella Septichora Visitor Centre, west of the parsonage, a passageway was built with the help of great engineering virtuosity by excavating under the parsonage itself. This corridor leads visitors to the magical space of the Cella Septichora. Returning from underneath the parsonage we can enter the world of the Wine Pitcher burial chamber. Going north, connecting the sites of burial chambers No. XIX, XX, V, III, IV and I and that of the Peter and Paul burial chamber, that had been built earlier, walking east 
inside the cellar and among the historic stones of the parsonage, the visitors reach a northsouth corridor that ends in the courtyard of the Cathedral Museum. North of it people can recall the Middle Ages by opening a sliding roof and entering the museum. Walking to the south we return to the upper level of the Cella Septichora and reach the entrance.

It is interesting to study the reactions of visitors to the site. Especially the common labourers are those who confirm the vision: they are moved by the spaces that had previously been unknown to them and understand the message of this 1600 year old new faith. They are not only interested in the children walking and playing on the glass ceiling, but they are also impressed by the prettier shapes. The well-travelled intellectual (who has never come across this type of site before), appreciate the uniqueness of this new protective building: the symbiosis of the antique culture and the new faith. Most importantly, the citizens of Pécs feel that this space is theirs. The Cella Septichora Visitors' Centre turned into a cultural meeting place. Concerts take place here, art exhibitions are organized, new books are launched, wedding ceremonies are held, etc. So this place is alive, it has become part of the promenade. The people of the $21^{\text {st }}$ century may travel in time through the exhibition of a $20^{\text {th }}$ century artist, under the baroque barrel vault and over the medieval walls into the Cathedral Museum where they can listen to an organ concert and end the journey in the shady park next to the town wall.



Fig. 14. The entrance of the Cella Septichora Visitors' Centre

It was a great step forward on this project that the architects managed to combine several smaller sites, however this is still insufficient. As the Early Christian burial ground, the 
bishop's palace, the buildings of the Middle Ages, Turkish times and the Baroque, which form quite an eclectic group, are built upon and next to one another, architects had to integrate this colourful and valuable historic mixture. The task was complimented with another task of making a connection between Széchenyi Square, which is the town's main square, and Cathedral Square. The promenade has been reconstructed and walkways were built along the inside of the western and northern town walls. Therefore, in addition to the uniqueness of the various historic periods built upon each other, there is another specialty offered to the citizens of Pécs: a chain of lush, green parks. In 2009, the bishopric of Pécs became 1000 years old. It celebrated this occasion with a great present: the façade of the buildings of the Cathedral Square, the Cathedral, the Bishop's Palace and the parsonage were all renovated. Today's Bishop's Palace, the walkways along the town walls and the world-class Early Christian cemetery all offer great experiences for both locals and international visitors, too. The north-western quarter of the historic town centre has never been so integrated and impressive as today. The establishment of the gardens adjoining the walkways along the northern and western town wall, the reconstruction of the Roman graves in Apáca Street and the renovation of the Civil Community House have all come true as part of this EU programme.

To complete the complex of buildings around the Bishop's Palace in all their splendour, one thing remains to be built. The task of saving the Cella Trichora plays a unique role in the history of Hungarian architecture. It represents the continuity between the Roman times and the Middle Ages because it still functioned as a church in the $11^{\text {th }}$ century.

\section{The Archaeology Museum}

The concept of the architects was for the reconstruction of the museum, preservation and establishment of connections. The mosque of Ghazi Kasim was built on the site of the former Saint Bartholomew church, whose ruins - according to an archaeological excavation carried out at the beginning of the $20^{\text {th }}$ century - can be found partly under the mosque and partly north of it, in front of the museum. With the reconstruction of a museum these unique artefacts could be presented to visitors.

\subsection{History of the museum building}

The Janus Pannonius Archaeology Museum is located on the main square of Pécs, at the eastern end of the reconstructed promenade (see Fig. 15). By walking west from the building, pedestrians can approach the buildings of the Early Christian burial ground. The building of the Archaeology Museum received its present form after a history of many centuries. According to the first land register, in 1687 the house of Ibrahim Csór, a janissary agha, was given to the Jesuits to be used for education purposes and it became a grammar school. In 1725 the building functions as a school of the Jesuits. From 1752 it became the house of a wine-merchant then in 1773, the house of the chamber. Between 1774 and 1822 the house was owned by the Országh family. Later it also functioned as an orphanage. In 1871 the Baranya County Savings and Credit Bank owned it and operated its bank there. In 1877 the building came into the possession of Kálmán Nádasdy who built the stone fence that can be seen today along the western side of the garden. In 1898 a new storey was added to the house that was designed and constructed by Imre Schlauch. The county purchased the house in 1941 in order to use it as a museum. Finally, in 1951 the house became 


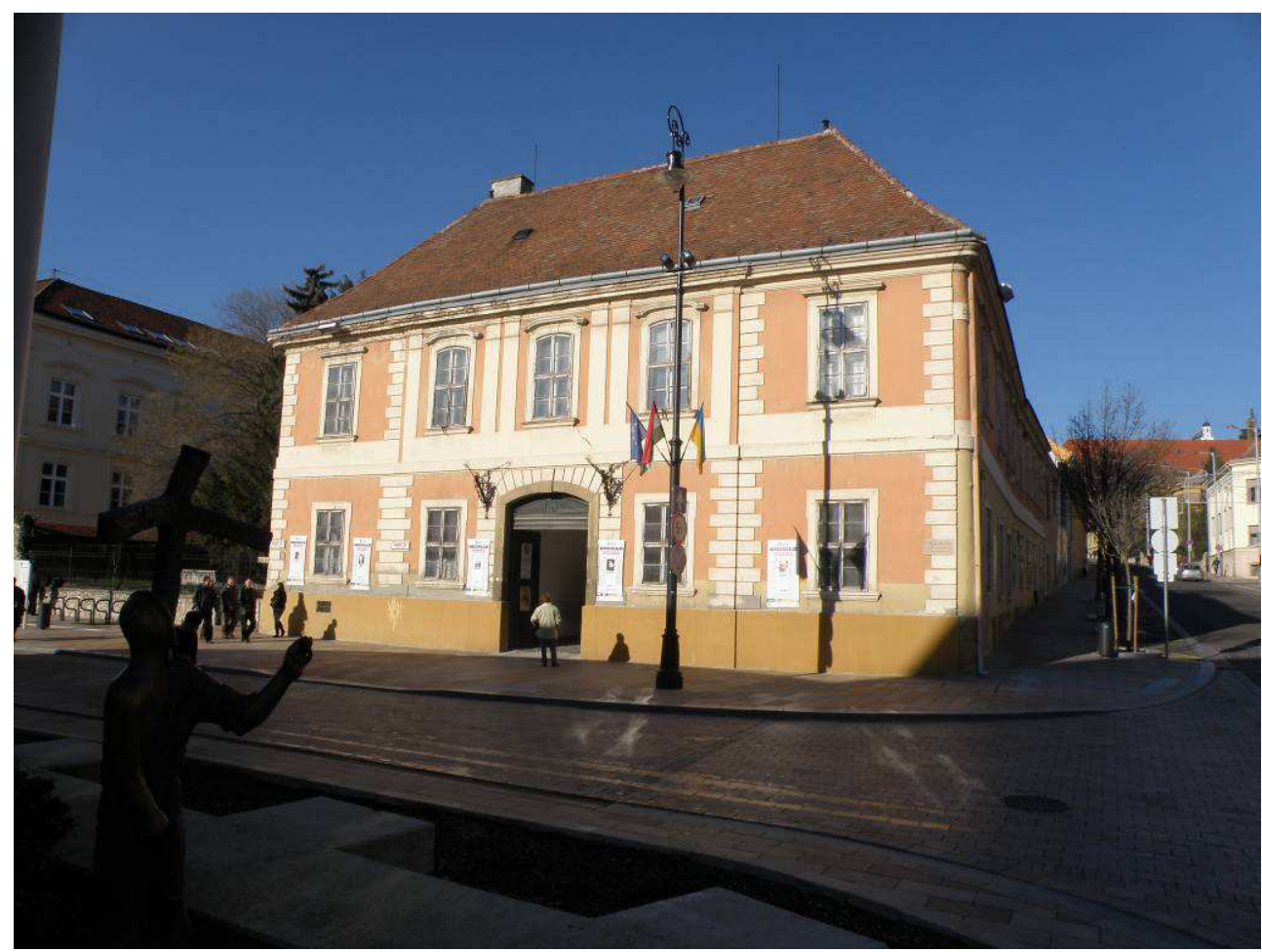

Fig. 15. Building of the Archaeology Museum in Pécs

government-owned and in addition to a department of archaeology, the Directorate of the Baranya County Museums was also located in the building. At the beginning of the 1960s a new wing was built along the northern part of the garden to house the Anthropology Collection. Towards the end of the 1970s, part of the attic was converted and the ceiling on the first floor was strengthened and the storerooms were modernized. The Anthropology Collection was placed into the storeroom in the attic while the Archaeology Collection was placed in the storeroom on the first floor of the east wing. The history of the house shows the various functions the building filled over the centuries when all of them played an important role in the life of Pécs for some reason or other.

\subsection{Concept for the reconstruction}

Over time the building of the Archaeology Museum has fallen into a derelict state. The overall superstructure is in a very good condition but it was obvious that this protected historic building needed renovation. The concept the architects had has always been about preservation and making connections. Preservation in the course of planning, the architects wanted to preserve everything possible and that which had not been added to the building arbitrarily. The word connection may have several meanings as roads, walkways, ages, buildings and underground spaces also intersect here. Underneath the museum there are ramifying tunnels connected to the cellars still existing under Széchenyi square. According 
to the original architectural concept the planners would not only create cellars under the periphery of the building to establish new exhibition halls, but this work would also have been extended to the south, towards the mosque. This way the ruins of the St. Bartholomew church could be presented (see Fig. 16).

Unfortunately, this southern extension did not fit into the financial framework provided by the investor. The architectural concept was thus limited to using the present cellars of the building and also to making new cellars under the periphery of the building. This does not mean that in the case of a future reconstruction of the building, the architects will not be able to use this underground world offering many great opportunities for improvement. As part of the building's reconstruction, the inner yard will have a glass ceiling, making it a multifunctional exhibition hall. By reconstructing the building of the museum, the planners can also make it accessible for disabled people, although within the limitations a historic building may have. The concept of the museum is also adjusted to the preservingconnecting philosophy of the architectural concept. Széchenyi square and the area west of it formed the historic centre of the town of Pécs. During the reconstruction works of the main square of Pécs in 2010, a burial chamber was found in front of the museum. For financial reasons this chamber was documented by the archaeologist and then reburied. It is quite probable that in the course of excavating the cellars, archaeologists could find several artefacts from the Roman period, which could then make the museum even more attractive. If there are interesting finds under the building then these could be displayed 'in situ' so the museum itself could become part of the exhibition. In this connection the museum, the exhibits, the attraction and its framework are all united. The various ages could also mean a further point of connection in the concept of the museum, as visitors will take a journey in time in the museum. Starting from the $21^{\text {st }}$ century show rooms on the first floor, visitors will be able to reach the time of the Roman Empire in the cellars through the Baroque period and the Middle Ages. A museum concept of this kind helps visitors connect the various archaeological finds to their periods and also understand them. In addition to these ideas, the architects wished to give the museum yet another role. Owing to its location and

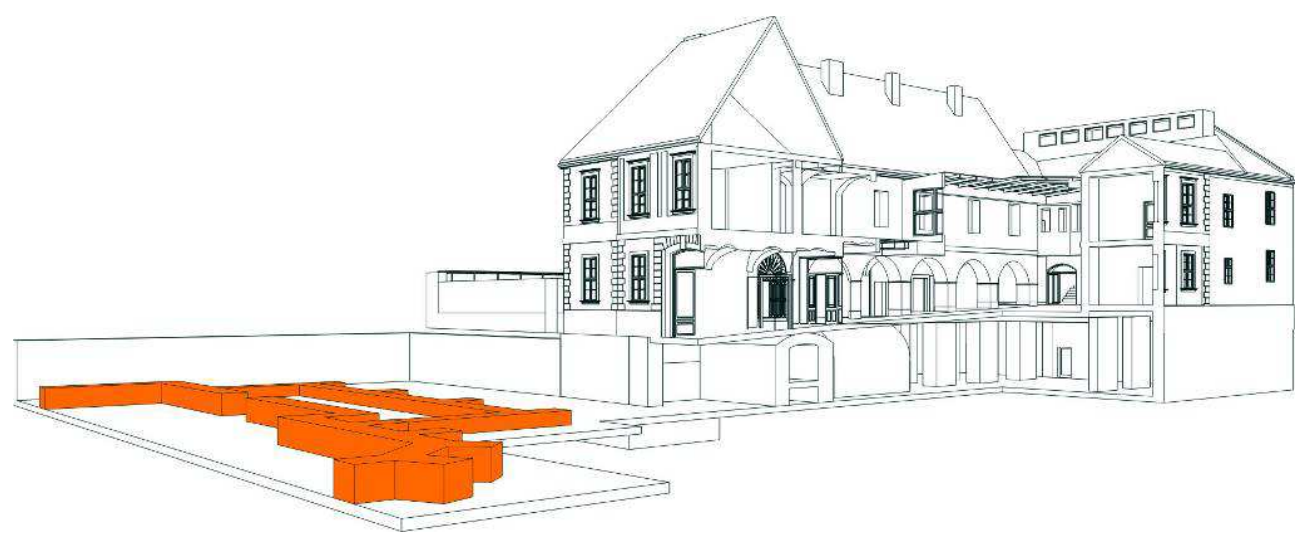

Fig. 16. The ruins of the St. Barholomew church in front of the Archaeology Museum 
because it is close to the walkways popular among tourists, the building could become the information centre of the World Heritage site. The tourists visiting Pécs can get the necessary information they need to discover this colourful town, which has been influenced by several cultures.

A row of arcades along the western side of the courtyard was walled up in the course of an earlier reconstruction. By undoing these, an architectural solution could be restored that could function really well, reducing the amount of sunlight the showrooms receive and meaning the employees would not have to use any additional shading. The geometry of the glass ceiling covering the inner yard of the museum would not be simple, as the height of the moulding, on parts of the building constructed over the various ages, are different from each other. The architects managed to design the geometry of the ceiling in a way that would ensure ventilation of the exhibition hall with the help of shutters. The designed architectural solutions are always separated from the existing structure under protection, ensuring faithfulness to the building and its didactic introduction. In the new spaces created by the enlargement of the underground level the vaulted cellars would appear as houses in the house providing the visitors with an interesting, new perspective. (Molnár, 2009)

The garden plays an important role in the architectural concept for various reasons. On one hand it is a green oasis in the museum, in the town and also in its main square; on the other hand the architects wish to display exhibits here that look like an open-air place, like a separate museum of stonework finds. At the same time, however, the youngest ones, the children should not be forgotten. Small interactive spaces in the garden were designed for them where they could get acquainted with the finds of the various periods in more intriguing, playful manner.

Unfortunately, the reconstruction of the Archaeology Museum in Pécs ground to a halt because of financial pressures of the investor. The architectural solutions to be implemented guarantee a framework for the concept of a museum where the architectural and archaeological remains of the early Christian period of the Roman Empire, the Middle Ages and the Turkish times as well as those of various ethnic groups (German, Croatian, Serbian, Turkish, Bulgarian) having inhabited the region since the beginning of the 19th century can be introduced. Hopefully the designed concept will be constructed in the near future.

\section{St. Bartholomew's bell-tower}

One of Europe's most beautiful pasha mosques decorates the main square of Pécs and is used as a catholic church. The congregation wanted to build a tower, a belfry, a campanile. This would have resulted in a rather strange architectural formation if the congregation had been called to mass by the peal of a relatively high campanile standing by the mosque. The architects finally had the idea of creating a sculpture composition, a bell sculpture, which rises like a tower while the bells are ringing and then sinks back to the size of a bell sculpture (Bachman, 2010).

The congregation of the City Centre Catholic Church, in Pécs' Széchenyi Square were longing for the ringing of bells for their church. It is quite understandable when you take into consideration that this is the square where János Hunyadi's statue reminds us of the Pope's call for all the bells of Europe to ring in remembrance of János Hunyadi, the Turk Conqueror. It is not a simple task to erect a tower; it could even be sacrilegious in this case 
for a mosque, even if it does serve as a catholic church today. A mosque can have a minaret, but it would be strange to hear bells from it. The mosque of Ghazi Kasim pasha was built from the stones of the St. Bartholomew's Church. In 1939 Gyula Gosztonyi excavated it and found the walls of the church's sanctuary.

\subsection{Concept of the bell tower}

Now anybody can experience the medieval treasure world of the missing church as the structure has been reconstructed and is now visible at a seated bench level. The square is neutral, very simple and can accept an almost undecorated tower. Three bells suspended from three slender steel columns, which statue-like guard the area to the north-east of the mosque with the statue of St. Bartholomew. It is a moving telescopic statue, which can hydraulically rise to become a tower (see Fig. 17). Technically, it consists of a thirteen meter

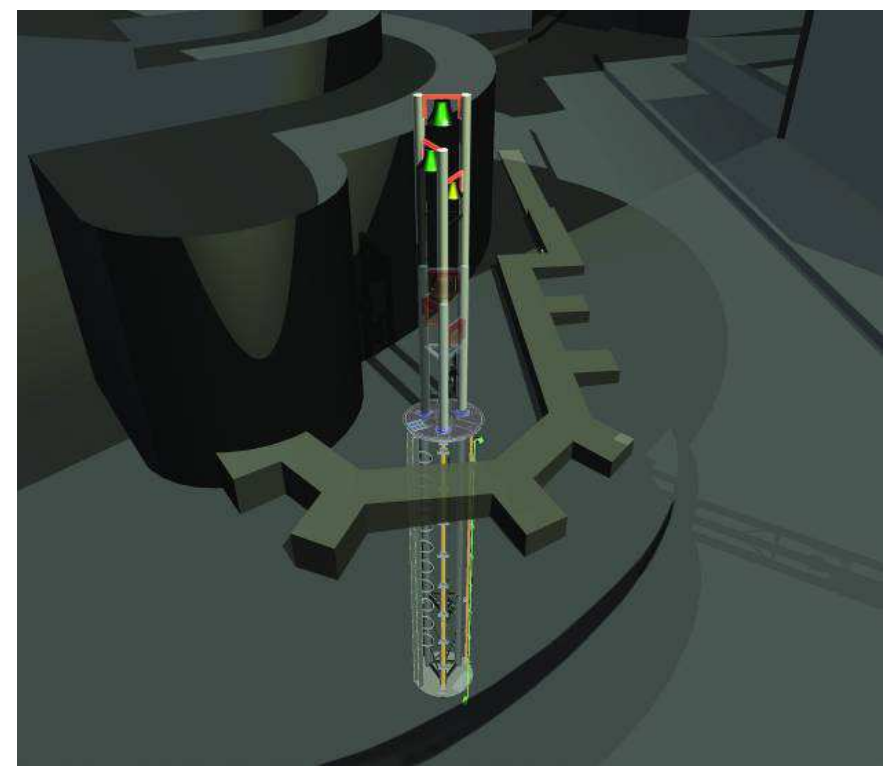

Fig. 17. Structural system of the moving bell tower

vertical shaft, two meters in diameter, which hides the steel structure of the tower, until it is raised the thirteen meters by a hydraulic drive with a five ton capacity.

The groundwork and creation of the shaft was done by a mining company. Erecting towers and statues, as well as the casting of the bells themselves have always been demanding communal activities. They have a symbolic power, expressing the unification of the settlement, they serve to protect, guard, sound the alarm, celebrate, mourn, orientate and are meeting points. (Bachmann \& Bachman, 2010)

It is an unforgettable, shocking and imposing experience to design and build a tower. It is a work giving faith and a test of professional competence, the power of soul and the 
omnipotence of fantasy. The erection of the tower was a determining moment for the design team. Work of the planners was guided by the love of the people, starting with the abbot, Pál Kele, through to the bishop and the congregation, their caring and protective concern, and sometimes their anxiety. It also inspired János Gulácsi, the classical master of bell ringing, who dreamt about a previously non-existing and invisible way of moving the bells. The sculptor, Sándor Rétfalvi's statue of St. Bartholomew is a significant piece of art: it is incredibly difficult to mark a point in space, perhaps impossible (see Fig. 18).

This point is the statue of St. Bartholomew, the martyr, who overcomes the torture of the fleeced, suffering man. The tower music was inspired by the movement of the sinking and rising sculpture-tower, the ringing of bells. The fresh rhythmic music, reminiscent of the striking and ringing of hammers in blacksmiths shops, is accompanied by the bass of a roarlike Gregorian song preaching timelessness. When reaching the final height, there is sparkling metallic music again to complete the 65-second rise, giving over to the magnificent ringing of bells, in the morning, at noon and in the evening.

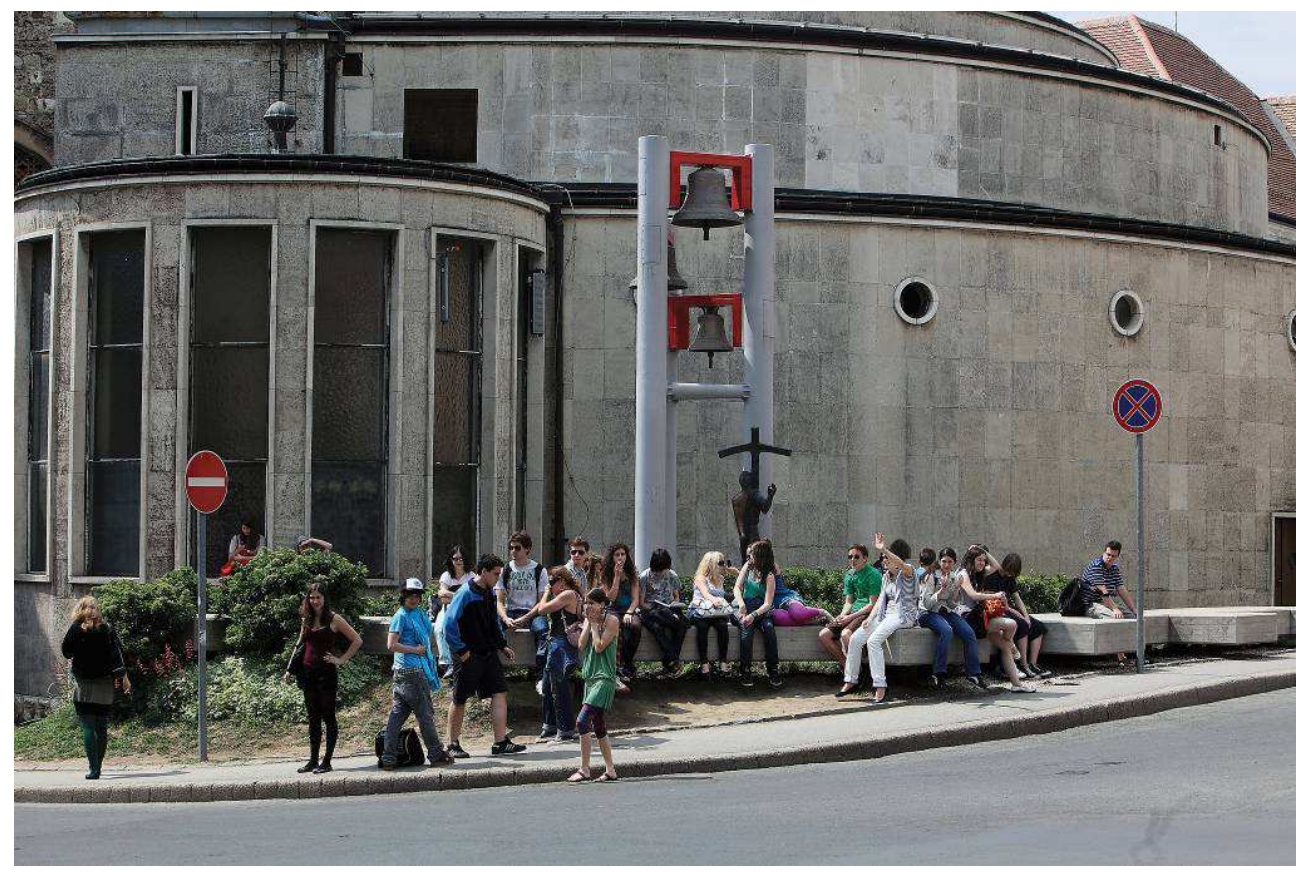

Fig. 18. St. Bartholomew bell tower with the sculpture of the martyr

\section{Conclusion}

During the projects some important principles of planning and research were laid down that are essential for the preservation and reconstruction of historical city centres.

The underground burial chamber renovation project needed special technical, architectural solutions. It was with the help of mining techniques that enabled the architects to protect 
these 1600 year old treasures. The burial buildings had to be isolated from the surrounding soil and buffer-zones were used to separate the painted burial chambers from the visitors, as the paintings need a constant temperature and humidity to remain preserved in a good condition.

I am of the opinion that these projects really represent the most important principle of monument protection, namely that the protected heritage should be presented in a way that everybody can understand it. In cases where only remnants of the original buildings remain, artistic effects should be used to present them. Special architectural solutions are needed to make visitors feel the atmosphere of the place.

Sustainability is also very important with such buildings and monuments. It is significant that these places are alive nowadays and that they are used for a variety of programmes not only as museums.

\section{Acknowledgment}

The author would like to express thanks for the works of the participants of the projects:

Dr. Zoltán Bachman, Dr. Bálint Bachmann, Dr. György Stocker, Dr. Tibor Kukai, Dr. István Kistelegdi, Dr. Krisztián Kovács-Andor, Dr. Mihály Schrancz, Dr. Adrienn Emresz, Dr. Gabriella Medvegy, Dr. Donát Rétfalvi, Dr. Tamás Kondor, Csaba Vezér, Ottó Viczencz, Magdolna Horváth, Ákos Lepsényi, György Halász, Júlia Borbély, Nóra Majoros and Dezső Benedek.

\section{References}

Z. Bachman. (2010) Bachman Zoltán, Vince Kiadó, Budapest

Z. Bachman, B. Bachmann. (2010) The cathedral museum of Pécs, Pollack Periodica, Akadémiai Kiadó, Budapest vol. 5. No. 3. 2010. pp 9-18.

Z. Bachman. (2009a) The Early Christian burial sites of Pécs/Sopianae as part of the world heritage, Pollack Periodica, vol. 4. No. 3. 2009. pp 11-32.

Z. Bachman. (2009b) Pécs/Sopianae Early Christian Cemetery Complex Cella Septichora Visitors' Centre, Magyar Építőipar Vol. LIX. No.5. pp. 162-170. Budapest

Z. Bachman, B. Bachmann. (2001) Architecture of the World Heritage in Pécs (in Hungarian: A világörökség védelmének épitészete Pécsett), Jelenkor, Vol. 44, No. 11, 2001, pp. 1143-1157.

Z. Bachman, F. Fülep. (1990) Pecs, the early Christian burial chamber to the Wine Pitcher (in Hungarian: Pécs, a "Korsós" ókeresztény sírkamra) Tájak Korok Múzeumok Kiskönyvtára, Vol. 373, 1990.

Z. Bachman. (1989) Architectural conservation Hungary's Roman underworld extensive architectural conservation of the Roman Mausoleum in Pécs including details of new public rooms for above group and underground viewing, The Journal of CIB Batiment International Building Research and Practice, Vol. 22, No. 1,1989, pp. 41-51.

Z. Bachman, F. Fülep, A. Pintér. (1988) Early Christian monuments of Sopianae-Pecs (in Hungarian: Sopianae-Pécs ókeresztény emlékei), Képzőmúvészeti Kiadó, Budapest, 1988. 
B. Bachmann. (2010) The Cathedral Museum of Pécs, ed. Cruz P. J. S. Structures and Architecture, CRC Press/Balkema, pp. 421, Leiden

B. Bachmann, Z. Bachman. (2010) St. Bartholomew's bell tower, Pollack Periodica, Akadémiai Kiadó, Budapest vol. 5. No. 3. 2010. pp 19-26.

B. Bachmann. (2002) Die Architektur zum Schutze des Weltkulturerbes in Pécs, Schild von Steier, Kleine Schriften, 19/2002. Landesmuseum Joanneum, pp. 11-29. Graz

K. Baliga. (2007) "Daylight" in Pecs, Cella Septichora Visitors' Centre, Régi Új Magyar Építőmúvészet Hungarian Architecture, No. 4, 2007, pp. 4-9.

F. Romvári F, D. Szilágyi. (ed.) (2005) Bachman Zoltán, Contemporary Art Pécs, Pécs, Alexandra Kiadó, 2005, pp. 137-143.

T. Molnár. (2009) The Reconstruction of the Archaeology Museum in Pécs, Pollack Periodica, Akadémiai Kiadó, Budapest (ISSN1788-1994) 2009. vol. 4. No. 3. pp 49-56. 


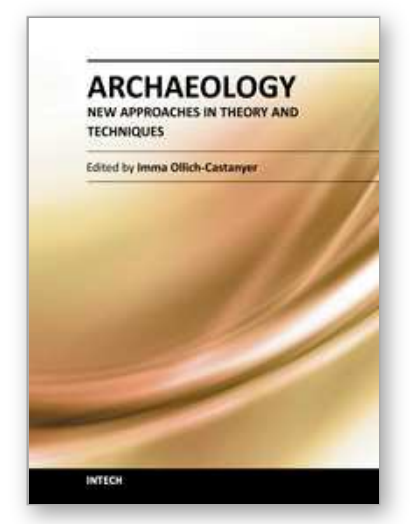

\author{
Archaeology, New Approaches in Theory and Techniques \\ Edited by Dr. Imma Ollich-Castanyer
}

ISBN 978-953-51-0590-9

Hard cover, 292 pages

Publisher InTech

Published online 09, May, 2012

Published in print edition May, 2012

The contents of this book show the implementation of new methodologies applied to archaeological sites. Chapters have been grouped in four sections: New Approaches About Archaeological Theory and Methodology; The Use of Geophysics on Archaeological Fieldwork; New Applied Techniques - Improving Material Culture and Experimentation; and Sharing Knowledge - Some Proposals Concerning Heritage and Education. Many different research projects, many different scientists and authors from different countries, many different historical times and periods, but only one objective: working together to increase our knowledge of ancient populations through archaeological work. The proposal of this book is to diffuse new methods and techniques developed by scientists to be used in archaeological works. That is the reason why we have thought that a publication on line is the best way of using new technology for sharing knowledge everywhere. Discovering, sharing knowledge, asking questions about our remote past and origins, are in the basis of humanity, and also are in the basis of archaeology as a science.

\title{
How to reference
}

In order to correctly reference this scholarly work, feel free to copy and paste the following:

Tamás Molnár (2012). Heritage Protection in Pécs/Sopianae, Archaeology, New Approaches in Theory and Techniques, Dr. Imma Ollich-Castanyer (Ed.), ISBN: 978-953-51-0590-9, InTech, Available from: http://www.intechopen.com/books/archaeology-new-approaches-in-theory-and-techniques/heritage-protectionin-p-cs-sopianae

\section{INTECH}

open science | open minds

\section{InTech Europe}

University Campus STeP Ri

Slavka Krautzeka 83/A

51000 Rijeka, Croatia

Phone: +385 (51) 770447

Fax: +385 (51) 686166

www.intechopen.com

\section{InTech China}

Unit 405, Office Block, Hotel Equatorial Shanghai

No.65, Yan An Road (West), Shanghai, 200040, China

中国上海市延安西路65号上海国际贵都大饭店办公楼 405 单元

Phone: +86-21-62489820

Fax: $+86-21-62489821$ 
(C) 2012 The Author(s). Licensee IntechOpen. This is an open access article distributed under the terms of the Creative Commons Attribution 3.0 License, which permits unrestricted use, distribution, and reproduction in any medium, provided the original work is properly cited. 